\title{
Analisis Pengaruh T-Shaped Slot Terhadap Kualitas Parameter Antena Mikrostrip menggunakan Computer Simulation Technology (CST) dan Advanced Design System (ADS) untuk Aplikasi Wi-Fi
}

\author{
Eka Setia Nugraha ${ }^{1}$, Widyana Paramitha ${ }^{2}$, Norma Amalia ${ }^{3}$ \\ ${ }^{1,2,3}$ Sekolah Tinggi Teknologi Telematika Telkom (ST3 Telkom) Purwokerto \\ 1,2,3 Jalan D.I Panjaitan No. 128 Purwokerto Jawa Tengah \\ Email korespondensi : eka_nugraha@st3telkom.ac.id
}

Dikirim 13 Mei 2017, Direvisi 31 Mei 2017, Diterima 20 Juli 2017

\begin{abstract}
Abstrak - Antena mikrostrip banyak digunakan karena memiliki beberapa keunggulan diantaranya yakni memiliki dimensi yang kecil dan bobot yang ringan, namun antena ini juga memiliki kekurangan yakni bandwidth yang terbatas serta gain yang rendah. Oleh sebab itu, antena ini dirancang dengan tujuan untuk memperoleh bandwidth yang lebar. Pada penelitian ini, dirancang dan disimulasikan antena mikrostrip patch rectangular T-shaped slot untuk mendukung komunikasi Wi-fi dengan menggunakan teknik pencatuan stripline. Antena yang dirancang dengan tujuan untuk memperoleh bandwidth yang lebar, diharapkan mampu menghasilkan karakteristik antena yang bekerja pada frekuensi tengah $2450 \mathrm{MHz}$ untuk nilai VSWR kurang dari 2 dengan jenis substrat yang digunakan adalah Epoxy FR4 dengan nilai permitivitas relatif $=4,4$, ketebalan 1,6 $\mathrm{mm}$, konstanta dielektrik 2,2 dan impedansi saluran mikrostrip $50 \Omega$ yang beroperasi pada frekuensi kerja 2,447 GHz. Dari hasil perancangan dengan simulator CST bandwidth yang dihasilkan sebesar $103 \mathrm{MHz}$, untuk nilai VSWR diperoleh nilai sebesar 1,367, gain sebesar 5,337 dB, dan direktivitas sebesar 6,238 dBi. Dan hasil perancangan dengan simulator ADS, nilai VSWR yang diperoleh sebesar 2,083, gain sebesar 0,505 dB, dan direktivitas sebesar 6,063 dBi.
\end{abstract}

Kata Kunci - Antena Mikrostrip, T-Shaped Antenna , Stripline, Wi-Fi

\begin{abstract}
Microstrip antenna is widely used because it has several advantages such as small dimension and light weight. However, this antenna also has weaknesses, which are limited bandwidth and low gain. Therefore, this antenna is designed for the purpose of obtaining a wide bandwidth. This research is to design and simulate a microstrip patch antenna rectangular T- shaped slot to support wi-fi communication and using stripline as a transmission line. An antenna designed for the purpose of obtaining a wide bandwidth, is expected to produce the characteristics of antennas working at a resonant frequency of $2447 \mathrm{MHz}$ for VSWR less than 2 with the type of substrate used is FR4 Epoxy with a relative permittivity value is 4.4, dielectric constanta is 2,2, and the thickness is 1,6, also impedance of transmission line is $50 \Omega$ that operate in frequency resonant $2,447 \mathrm{GHz}$. According to design and simulation this antenna, value of bandwidth impedance is about $103 \mathrm{MHz}$ for VSWR 1,367 , gain about $5,337 \mathrm{~dB}$, and directivity about $6,238 \mathrm{dBi}$. And the result of simulation on ADS simulator, the value of VSWR is 2,083 , with gain about $0,505 \mathrm{~dB}$, and directivity about $6,063 \mathrm{dBi}$.
\end{abstract}

Keywords - Microstrip Antenna, T-shaped Antenna, Miccrostrip Line, Wi-Fi

\section{PENDAHULUAN}

Wireless Fidelity (Wi-Fi) merupakan teknologi masa depan, Dalam suatu sistem komunikasi tanpa kabel (wireless) yang mampu mengakomodasi berbagai perangkat ke jaringan komputer yang bekerja pada frekuensi $2,4 \mathrm{GHz}$ dan $5 \mathrm{GHz}$. Saat ini beberapa perangka yang menggunakan $\mathrm{Wi}-\mathrm{Fi}$ adalah Personal Computer (PC), video-game consoles, smart phones, kamera digital, dan komputer tablet [1], gelombang elektromagnetik merambat dari pemancar 
ke penerima melalui ruang bebas. Pada sistem tersebut digunakan antena. Dengan kata lain, antena merupakan suatu alat yang digunakan untuk memancarkan dan menerima gelombang elektromagnetik. Antena merupakan elemen paling penting dalam mendukung suatu sistem komunikasi. Salah satu antena yang banyak digunakan saat ini adalah antena mikrostrip. Antena mikrostrip banyak digunakan karena memiliki beberapa keunggulan diantaranya yakni memiliki dimensi yang kecil dan bobot yang ringan. Namun, antena ini juga memiliki kekurangan yakni bandwidth yang terbatas serta gain yang rendah.

Antena ini dimodifikasi dengan membuat slot berbentuk " $T$ " pada patch rectangular. Pada patch yang berbentuk rectangular, dimensi panjang dan lebar patch tersebut akan berpengaruh terhadap frekuensi kerja antena[2]. Sedangkan, pada konfigurasi T-Shaped akan mempengaruhi impedansi antena, dan VSWR, kemudian berpengaruh pada bandwidth antena [7][8][10]. Hal ini seperti penelitian sebelumnya[3][9][12][13] yang menggunakan beberapa bentuk patch untuk memperbesar bandwidth antena. Dan berbagai variasi antena mikrostrip yang ada dalam penelitian [4].

Pada penelitian ini dianalisis sejauh mana modifikasi pada patch dan T-Shaped akan mempengaruhi frekuensi kerja serta bandwith antena, serta membandingkan kualitas yang lebih baik terhadap kedua modifikasi diatas. Antena ini dirancang untuk dapat beroperasi pada teknologi WiFi. WiFi merupakan sebuah teknologi yang memanfaatkan peralatan elektronik untuk bertukar data secara nirkabel (menggunakan gelombang radio) yang banyak dipergunakan untuk koneksi internet berkecepatan tinggi[6]. Perancangan dan simulasi antena ini akan menggunakan software Computer Simulation Technology (CST) yang merupakan software simulasi sampai ke bagian terkecil antena berupa sel bahan dan mengoptimasikannya[14]. Dan Advanced Design System (ADS) merupakan software simulasi yang dapat digunakan untuk membuat layout desain antena kemudian disimulasikan dalam kawasan frekuensi dan waktu[15]. Setelah berhasil disimulasikan, selanjutnya membandingkan kedua konfigurasi antena dengan dua software yang digunakan.

\section{METODE PENELITIAN}

Pada penelitian ini, dirancang sebuah antena mikrostrip T-shaped slot yang digunakan untuk mendukung komunikasi WiFi. Spesifikasi antena yang digunakan dalam perancangan ini adalah sebagai berikut.

a. Frekuensi $=2400-2500 \mathrm{MHz}$

b. Er bahan FR4 (epoxy) $=4,4$

c. Tebal patch $=0,035 \mathrm{~mm}$

d. Tebal substrat $=1,6 \mathrm{~mm}$
Perancangan antena dalam penelitian ini terbagi atas beberapa tahapan pokok yaitu tahap penentuan spesifikasi antena, tahap perhitungan dimensi antena, tahap perancangan antena, tahap simulasi, dan tahap analisa hasil data. Tahapan perancangan dapat digambarkan dalam flow chart berikut.

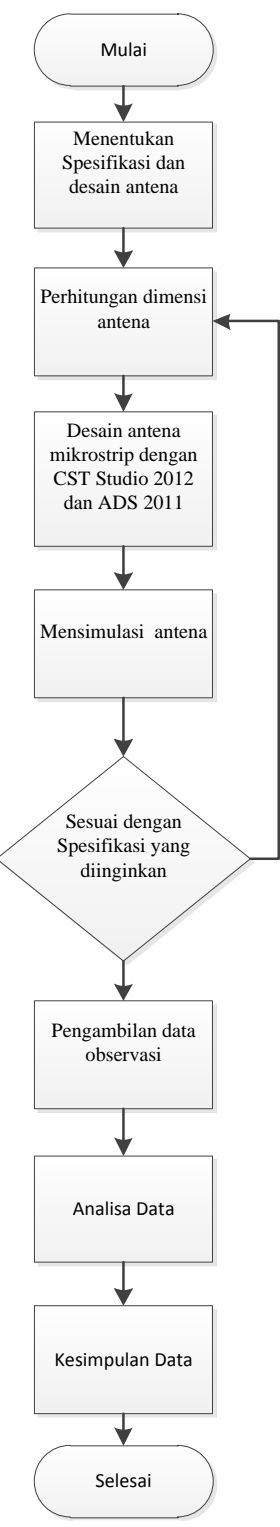

Gambar 1. Flow Chart Perancangan Antena

\section{A. Perhitungan Dimensi Antena}

Setelah menentukan spesifikasi antena, tahapan selanjutnya yakni menghitung dimensi antena yang akan dirancang. Persamaan-persamaan yang digunakan untuk perhitungan dimensi antena [4] [5][11].

1) Menghitung Lebar patch (W):

$$
W=\frac{C}{2 x f_{c} \sqrt{\frac{\varepsilon_{r}+1}{2}}}
$$

2) Menghitung konstanta dielektrik efektif : 


$$
\varepsilon_{\text {eff }}=\frac{\varepsilon_{r}+1}{2}+\frac{\varepsilon_{r}-1}{2}\left(1+12 \times \frac{h}{W}\right)^{-1 / 2}
$$

3) Menghitung panjang patch (L):

$$
L_{\text {eff }}=\frac{C}{2 x f_{c \sqrt{\varepsilon_{e f f}}}}
$$

4) Menghitung Panjang Efektif Patch :

$$
\Delta L=0,412 h\left[\frac{\left(\varepsilon_{e f f}+0,3\right)\left(\frac{W}{h}+0,264\right)}{\left(\varepsilon_{e f f}-0,258\right)\left(\frac{W}{h}+0,8\right)}\right]
$$

5) Menghitung Panjang Patch (L)

$$
L=L_{\text {eff }}-2 \Delta L
$$

6) Menghitung dimensi saluran pencatu dengan impedansi $50 \Omega$ :

$$
\begin{aligned}
& B=\frac{60 \pi^{2}}{Z_{0} \sqrt{\varepsilon_{r}}} \\
& W s t=\frac{2 h}{\pi}\{B-1-\ln (2 B- \\
& \left.1)+\frac{\varepsilon_{r}-1}{2 \times \varepsilon_{r}}\left[\ln (B-1)+0,39-\frac{0,61}{\varepsilon_{r}}\right]\right\}
\end{aligned}
$$

Untuk menghitung konstanta dielektrik efektif pada saluran pencatu :

Jika W/h > 1 :

$$
\begin{aligned}
& \varepsilon_{\text {eff }}=\frac{4,4+1}{2}+\frac{4,4-1}{2}\left[\frac{1}{\sqrt{1+12\left(\frac{1,6}{3,06111}\right)}}\right] \\
& \lambda_{0}=\frac{c}{f_{c}} \\
& \lambda_{g}=\frac{\lambda_{0}}{\sqrt{\varepsilon_{e f f}}} \\
& \text { Lst }=\frac{\lambda_{g}}{4} \\
& \text { Untuk Pergeseran frekuensi } \\
& L_{0}=\left(\frac{\text { frek.X }}{\text { frek.center }}\right) \times L_{0}
\end{aligned}
$$

Dimana :

Frek. $\mathrm{X} \quad=$ frekuensi yang dihasilkan

Frek.center $\quad=$ frekuensi center

$\mathrm{L}_{0} \quad=$ panjang patch antena

\section{HASIL PENELITIAN}

A. Hasil Simulasi Antena Single Patch menggunakan Dimensi perhitungan.

Dalam simulasi sesuai perhitungan hasil parameter pengukuran belum sesuai spesifikasi, terutama frekuensi kerja belum sesuai dengan yang ditentukan. Berikut merupakan hasil optimasi dengan pergeseran frekuensi seperti persamaan (12). Maka diperoleh nilai sebagai berikut.

Tabel 1. Dimensi Optimasi Antena Single Patch Pada CST.

\begin{tabular}{ccccc}
\hline $\begin{array}{c}\text { Panjang } \\
\text { Patch }\end{array}$ & $\begin{array}{c}\text { Lebar } \\
\text { Patch }\end{array}$ & $\begin{array}{c}\text { Return loss } \\
(\mathbf{d B})\end{array}$ & $\begin{array}{c}\text { VSW } \\
\mathbf{R}\end{array}$ & $\begin{array}{c}\text { Frek. } \\
(\mathbf{G H z})\end{array}$ \\
\hline 28,85 & 37,306 & $-6,334$ & 2,863 & 2,338 \\
27,22 & 37,306 & $-6,941$ & 2,634 & 2,436 \\
28,32 & 37,306 & $-6,946$ & 2,633 & 2,447 \\
\hline
\end{tabular}

Tabel 2. Dimensi Optimasi Antena Single Patch Pada ADS

\begin{tabular}{ccccc}
\hline $\begin{array}{c}\text { Panjang } \\
\text { Patch }\end{array}$ & $\begin{array}{c}\text { Lebar } \\
\text { Patch }\end{array}$ & $\begin{array}{c}\text { Return loss } \\
(\mathbf{d B})\end{array}$ & $\begin{array}{c}\text { VSW } \\
\text { R }\end{array}$ & $\begin{array}{c}\text { Frek. } \\
(\mathbf{G H z})\end{array}$ \\
\hline 28,85 & 37,306 & $-4,975$ & 3,587 & 2,4
\end{tabular}

\begin{tabular}{ccccc}
\hline $\begin{array}{c}\text { Panjang } \\
\text { Patch }\end{array}$ & $\begin{array}{c}\text { Lebar } \\
\text { Patch }\end{array}$ & $\begin{array}{c}\text { Return loss } \\
(\mathbf{d B})\end{array}$ & $\begin{array}{c}\text { VSW } \\
\text { R }\end{array}$ & $\begin{array}{c}\text { Frek. } \\
(\mathbf{G H z})\end{array}$ \\
\hline 27,32 & 37,306 & $-5,252$ & 3,408 & 2,544 \\
28,358 & 37,306 & $-5,252$ & 3,408 & 2,447 \\
\hline
\end{tabular}

a) Nilai Return loss

Pada gambar 2 menunjukkan nilai return loss yang dihasilkan setelah dilakukan pergeseran frekuensi menggunakan CST. Pada frekuensi rendah $2,4 \mathrm{GHz}$ sebesar $-5,932 \mathrm{~dB}$, pada frekuensi tengah 2,447 $\mathrm{GHz}$ sebesar $-6,946 \mathrm{~dB}$ dan pada frekuensi tinggi 2,494 GHz memiliki nilai $-5,344$.

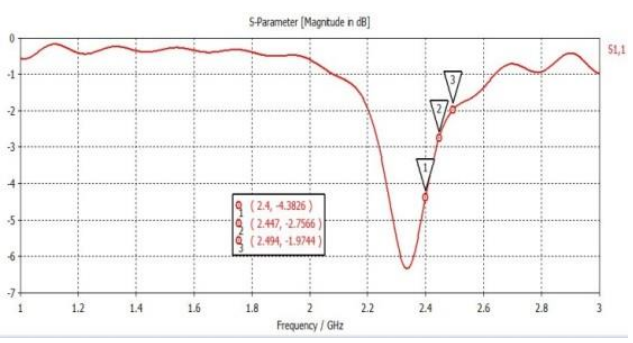

Gambar 2. Nilai Optimasi Return Loss Antena Single Patch CST

Pada Gambar 3 menunjukkan hasil dari pergeseran frekuensi pada return loss menggunakan ADS. Return loss yang dihasilkan frekuensi rendah $2,4 \mathrm{GHz}$ adalah sebesar $-5,077$ dB. Pada frekuensi tengah $2,447 \mathrm{GHz}$ menghasilkan return loss sebesar $-5,077 \mathrm{~dB}$, dan pada frekuensi tinggi $2,494 \mathrm{GHz}$ menghasilkan return loss sebesar $-4,390 \mathrm{~dB}$.

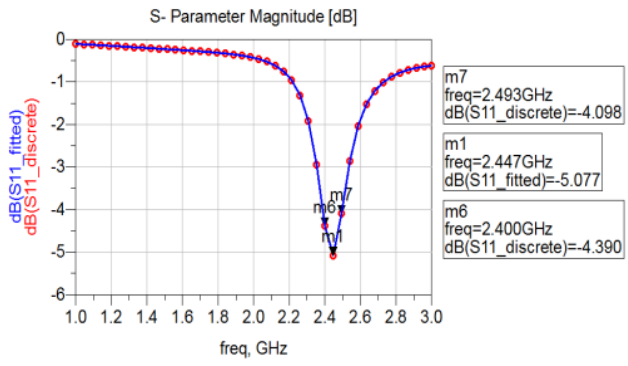

Gambar 3. Nilai Optimasi Return Loss Antena Single Patch ADS

Dari kedua simulasi yang dilakukan terhadap kedua simulator CST dan ADS, dapat diambil kesimpulan bahwa optimasi yang dilakukan pada antena single patch rectangular masih belum dapat memenuhi syarat spesifikasi nilai return loss yakni $\leq 10 \mathrm{~dB}$ terhadap frekuensi kerja 2,447 $\mathrm{GHz}$.

b) Nilai VSWR

Pada Gambar 4 menunjukkan hasil yang didapat untuk parameter VSWR menggunakan CST. Pada frekuensi rendah 2,4 $\mathrm{GHz}$ menghasilkan nilai VSWR sebesar 3,041. Pada frekuensi tengah $2,447 \mathrm{GHz}$ menghasilkan nilai 
VSWR sebesar 2,633 dan pada frekuensi tinggi 2,494 GHz menghasilkan frekuensi sebesar 3,352.

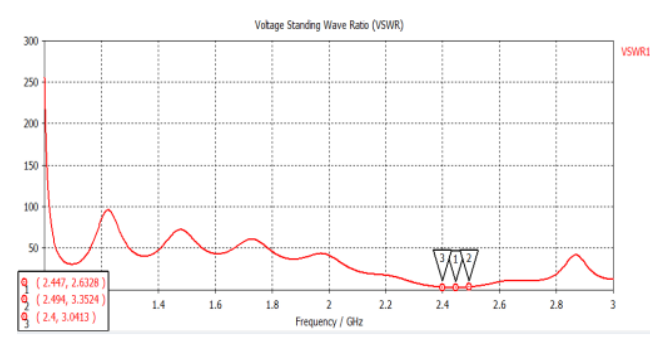

Gambar 4. Nilai Optimasi VSWR Antena Single Patch CST

Dan pada Gambar 5 menunjukkan hasil yang didapat untuk parameter VSWR pada antena mikrostrip patch rcctangular menggunakan simulator ADS. Nilai VSWR yang diperoleh menggunakan simulator ADS memiliki nilai yang berbeda dengan nilai VSWR yang diperoleh menggunakan simulator CST. Pada frekuensi rendah 2,4 GHz menghasilkan nilai VSWR sebesar 4,041. Pada frekuensi tengah 2,447 GHz menghasilkan nilai VSWR sebesar 3,518 dan pada frekuensi tinggi 2,494 GHz menghasilkan VSWR sebesar 4,317.

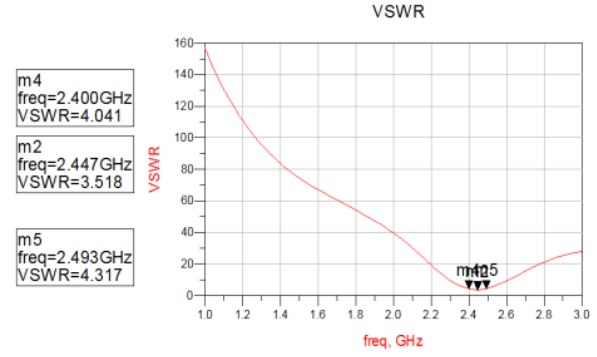

Gambar 5. Nilai Optimasi VSWR Antena Single Patch ADS

Dari kedua simulasi yang dilakukan terhadap kedua simulator CST dan ADS, dapat diambil kesimpulan bahwa optimasi yang dilakukan pada antena single patch rectangular masih belum dapat memenuhi syarat spesifikasi nilai VSWR yakni $\leq 2$ terhadap frekuensi kerja 2,447 GHz.

c) Nilai Gain

Nilai gain yang dihasilkan setelah dilakukan pergeseran frekuensi menggunakan CST ditunjukkan pada Gambar 6. Pada frekuensi kerja $2,447 \mathrm{GHz}$, nilai gain yang didapat adalah sebesar $3,458 \mathrm{~dB}$.

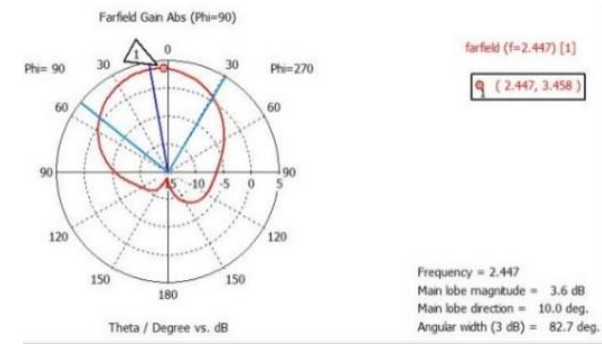

Gambar 6. Nilai Optimasi Gain Antena Single Patch CST
Nilai gain yang dihasilkan setelah dilakukan pergeseran frekuensi menggunakan ADS ditunjukkan pada Gambar 7. Pada frekuensi kerja $2,447 \mathrm{GHz}$, nilai gain yang didapat adalah sebesar $2,6558 \mathrm{~dB}$.

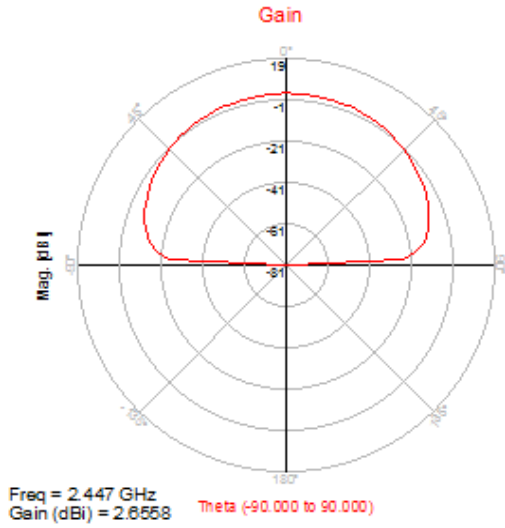

Gambar 7. Nilai Optimasi Gain Antena Single Patch ADS

Dari kedua simulasi yang dilakukan terhadap kedua simulator CST dan ADS, dapat diambil kesimpulan bahwa nilai gain yang dihasilkan pada simulator CST masih jauh lebih baik dibandingkan dengan nilai gain yang dihasilkan pada simulator ADS.

d) Nilai Pola Radiasi

Pada gambar 8 menunjukkan bentuk pancaran sinyal dari antena T-shaped slot yakni unidirectional. Bentuk pancaran sinyal menuju ke satu arah dengan daya pancar antena sebesar $8,514 \mathrm{dBW} / \mathrm{m}^{2}$.

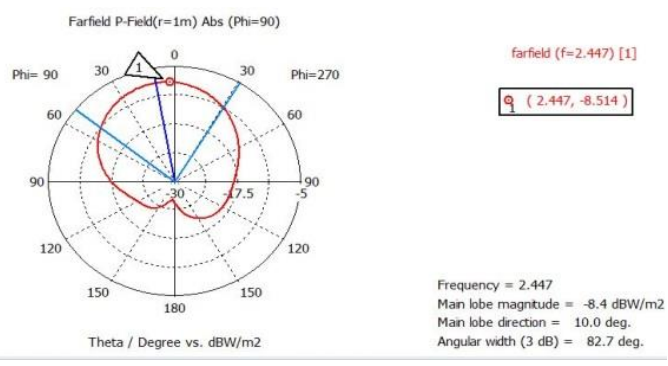

Gambar 8. Nilai Optimasi Pola Radiasi Antena Single Patch CST

Pada Gambar 9 menunjukkan bentuk pancaran sinyal dari antenaT-shaped slot pada simulator ADS yakni unidirectional. Bentuk pancaran sinyal menuju ke satu arah dengan efisiensi daya pancar sebesar 49,47\%. 


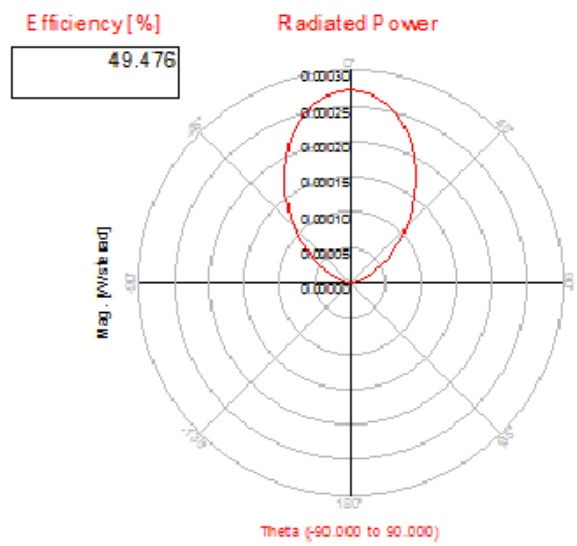

Gambar 9 Nilai Optimasi Pola Radiasi Antena Single Patch ADS

Berdasarkan simulasi yang telah dilakukan pada simulator CST dan ADS dapat diambil kesimpulan bahwa optimasi yang dilakukan pada antena single patch rectangular tidak mengubah bentuk pancaran dari antena.

B. Hasil Data Antena Single Patch Dengan T-shaped Slot

Hasil data yang diperoleh dari perancangan antena T-shaped slot dengan menggunakan CST dan ADS ditunjukkan pada Tabel 3 dan Tabel 4.

Tabel 3. Hasil Data Antena Rectangular dan T-shaped slot

\begin{tabular}{lccccccc}
\hline \multicolumn{3}{c}{ Rectangular } & & \multicolumn{3}{c}{ T-Shaped Slot } \\
\hline & rL(dB) & Gain (dB) & VSWR & rL(dB) & $\begin{array}{l}\text { Gain } \\
(\mathbf{d B})\end{array}$ & VSWR \\
\hline CST & $-6,946$ & 3,458 & 2,633 & $-9,358$ & 1,493 & 2,006 \\
ADS & $-5,072$ & 2,656 & 3,518 & $-8,082$ & 0,560 & 2,302 \\
\hline
\end{tabular}

Tabel 4. Hasil Data Optimasi Antena T-shaped slot dengan CST dan ADS

\begin{tabular}{cccccc}
\hline \multicolumn{5}{c}{ T-Shaped Slot Hasil Optimasi } \\
\hline & rL (dB) & Gain (dB) & VSWR & Direktivitas & BW \\
\hline CST & $-16,195$ & 5,28 & 1,367 & 6,238 & $\begin{array}{c}103 \\
\text { Mhz }\end{array}$ \\
ADS & $-9,088$ & 0,505 & 2,083 & 6,063 & - \\
\hline
\end{tabular}

a) Return loss Pada Antena Single Patch Dengan T-shaped Slot

Grafik nilai return loss pada simulator CST dapat dilihat pada Gambar 10. Nilai minimum return loss yang dihasilkan berdasarkan simulasi adalah sebesar $-16,195 \mathrm{~dB}$ pada frekuensi kerja 2,447 GHz, pada frekuensi $2.4 \mathrm{GHz}$ return loss yang dihasilkan sebesar $-10,04$ dan nilai return loss yang dihasilkan pada frekuensi tinggi 2,494 $\mathrm{GHz}$ adalah sebesar $-10,135$. Hal ini menunjukkan bahwa nilai return loss yang dihasilkan pada frekuensi yang dirancang sudah memenuhi spesifikasi umum antena mikrostrip yakni $\leq-10$ $\mathrm{dB}$.

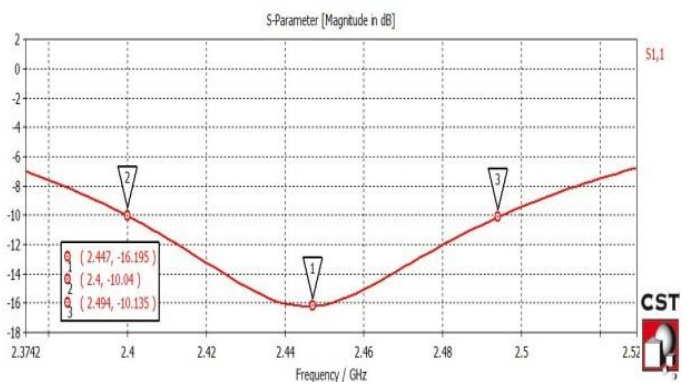

Gambar 10. Return Loss Hasil Optimasi Antena T-Shaped Slot CST

Pada Gambar 11 menunjukkan nilai return loss yang dihasilkan menggunakan simulator ADS. Pada frekuensi kerja $2,447 \mathrm{GHz}$ nilai minimum return loss yang dihasilkan adalah sebesar -9,088 dB, pada frekuensi $2,4 \mathrm{GHz}$ menghasilkan return loss sebesar $-7,490 \mathrm{~dB}$ dan pada frekuensi tinggi $2,494 \mathrm{GHz}$ menghasilkan return loss sebesar $-7,066 \mathrm{~dB}$.

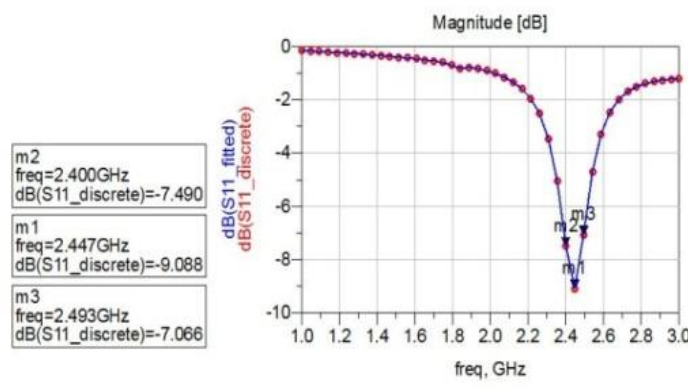

Gambar 11. Return Loss Hasil Optimasi Antena T-Shaped Slot ADS

b) VSWR pada Antena Single Patch dengan Tshaped slot

Pada Gambar 12 menunjukkan nilai VSWR yang dihasilkan pada antena mikrostrip T-shaped slot. Nilai VSWR yang dihasilkan pada frekuensi kerja 2,447 GHz adalah sebesar 2,006.

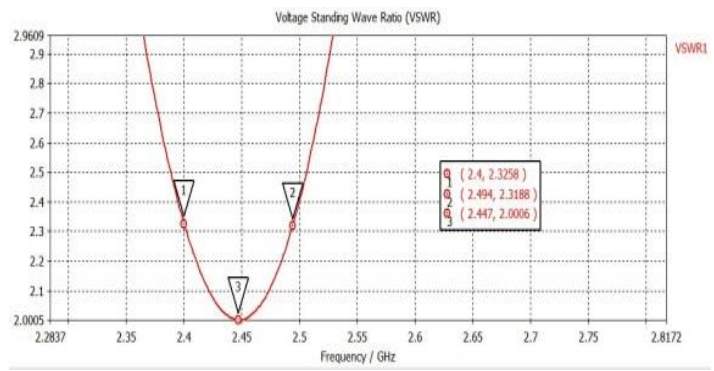

Gambar 12. VSWR Antena T-Shaped Slot

Dan, pada Gambar 13 menunjukkan nilai VSWR yang dihasilkan pada antena single patch rectangular pada frekuensi kerja $2,447 \mathrm{GHz}$ adalah sebesar 2,9781. Nilai VSWR yang dihasilkan 
antena mikrostrip T-shaped slot jauh lebih baik dibandingkan dengan nilai VSWR antena single patch rectangular.

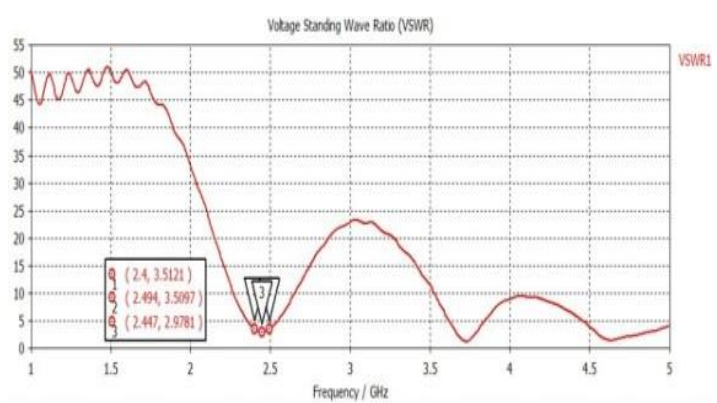

Gambar 13. VSWR Antena Single Patch Rectangular

c) Gain pada Antena Single Patch dengan Tshaped slot

Pada Gambar 14 menunjukkan nilai gain yang dihasilkan antena mikrostrip T-shaped slot pada frekuensi kerja 2,447 $\mathrm{GHz}$ adalah sebesar 1,493 $\mathrm{dB}$.

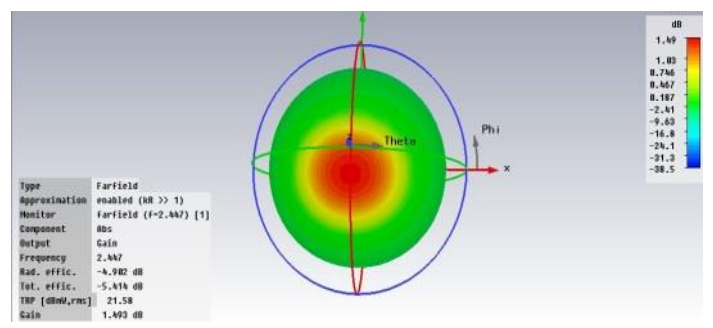

Gambar 14. Gain Antena Mikrostrip T-Shaped Slot

Sedangkan, pada Gambar 15 menunjukkan nilai gain yang dihasilkan antena single patch rectangular yaitu sebesar $3,802 \mathrm{~dB}$.

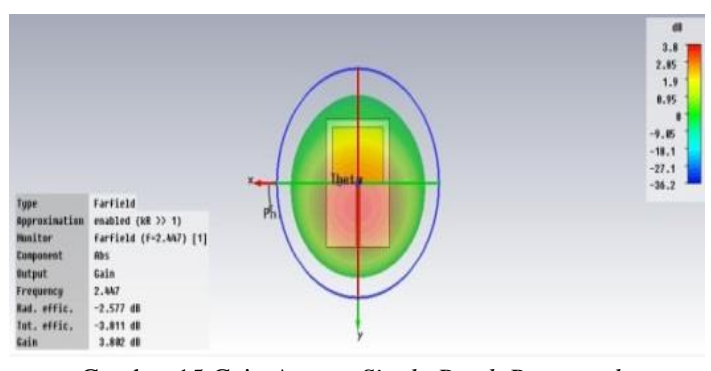

IV. PEMBAHASAN

\section{A. Pengaruh Dimensi T-Shaped Slot Pada CST}

Pada Gambar 16, dapat dilihat bahwa nilai return loss yang paling baik adalah ketika dimensi LT pada T-shaped slot bernilai $9 \mathrm{~mm}$ dengan nilai return loss sebesar $-9,2044 \mathrm{~dB}$.

Pada Gambar 17 menunjukkan grafik perubahan dimensi WT pada T-shaped slot terhadap parameter return loss. Dimensi terbaik yang didapat adalah 3,08 dan 1,8 mm dengan nilai return loss sebesar $-9,395$ $\mathrm{dB}$.

Pada Gambar 18 menunjukkan grafik perubahan dimensi LT2 pada T-shaped slot terhadap parameter return loss. Dari hasil grafik yang ditunjukkan dapat dilihat bahwa nilai return loss terbaik yang dihasilkan adalah sebesar $-9,5396 \mathrm{~dB}$ dengan dimensi LT2 sebesar $6 \mathrm{~mm}$.

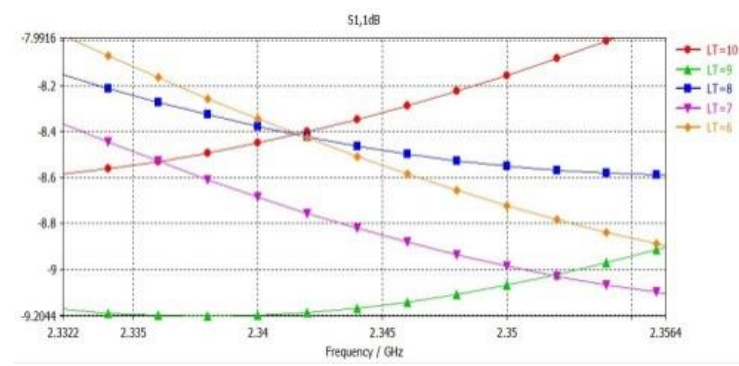

Gambar 16. Perubahan Dimensi LT Terhadap Return Loss

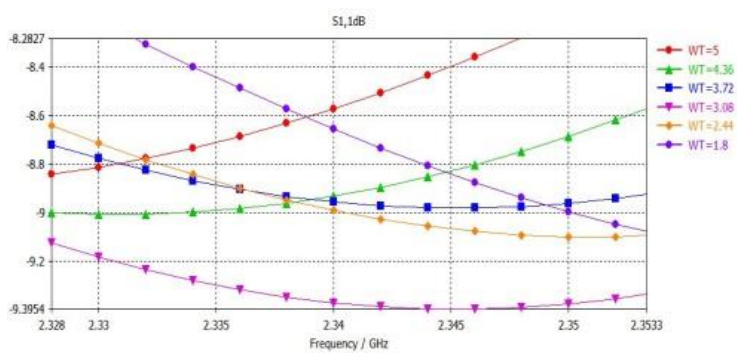

Gambar 17. Perubahan Dimensi WT Terhadap Return Loss

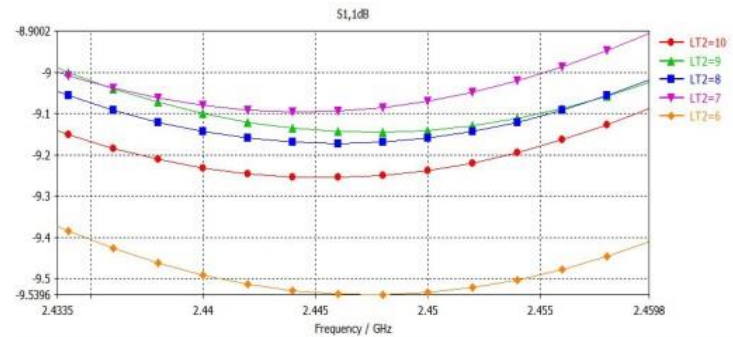

Gambar 18. Perubahan Dimensi LT2 Terhadap Return Loss

a) Pengaruh Dimensi T-shaped slot terhadap VSWR

Perubahan dimensi T-shaped slot mempengaruhi parameter VSWR pada antena. Hal ini ditunjukkan pada grafik Gambar 19. Nilai VSWR yang paling yaitu sebesar 2,061 dengan dimensi LT sebesar $9 \mathrm{~mm}$.

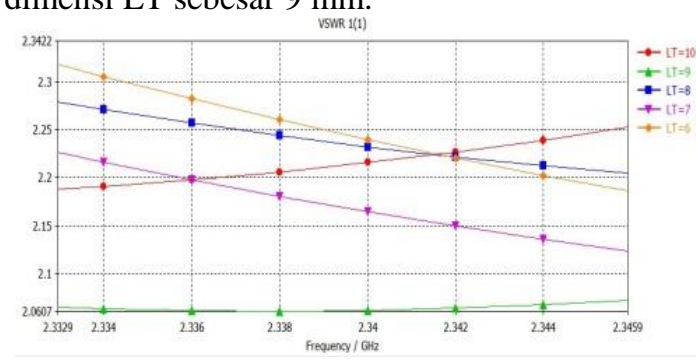

Gambar 19. Perubahan Dimensi LT Terhadap VSWR 
Pada Gambar 20 menunjukkan perubahan dimensi WT antena T-shaped slot terhadap parameter VSWR. Nilai VSWR yang balik yakni sebesar 2,0258 dengan dimensi WT sebesar 3,08 $\mathrm{mm}$.

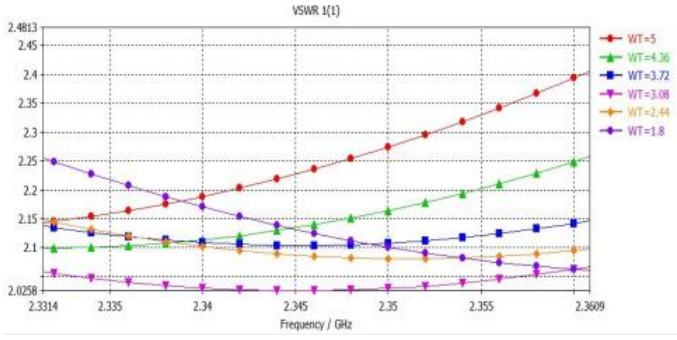

Gambar 20. Perubahan Dimensi WT Terhadap VSWR

Kemudian, perubahan dimensi LT2 terhadap VSWR ditunjukkan pada Gambar 21. Dari hasil grafik, dapat dilihat nilai VSWR terbaik adalah 2,005 dengan dimensi LT sebesar $6 \mathrm{~mm}$.

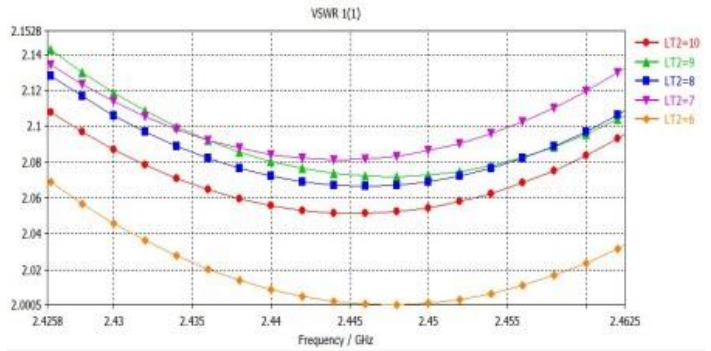

Gambar 21. Perubahan Dimensi LT2 Terhadap VSWR

b) Pengaruh Dimensi T-shaped slot Terhadap Gain

Pada Gambar 22 menunjukkan nilai gain yang paling baik adalah sebesar 1,738 $\mathrm{dB}$ dengan dimensi antena LT sebesar $6 \mathrm{~mm}$.

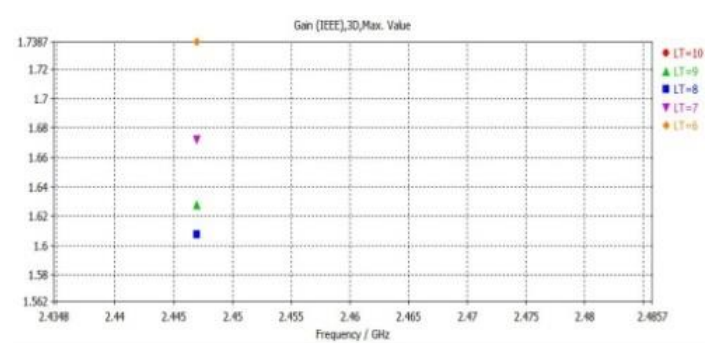

Gambar 22. Perubahan Dimensi LT Terhadap Gain

Pada Gambar 23 menunjukkan nilai gain yang paling baik adalah sebesar 1,7 dB dengan dimensi WT sebesar 3,08 dan 1,8 mm. Pada Gambar 24 menunjukkan pengaruh dimensi LT2 terhadap parameter gain. Nilai gain terbaik yang dihasilkan adalah sebesar 1,6837 dB dengan dimensi LT2 sebesar $7 \mathrm{~mm}$.

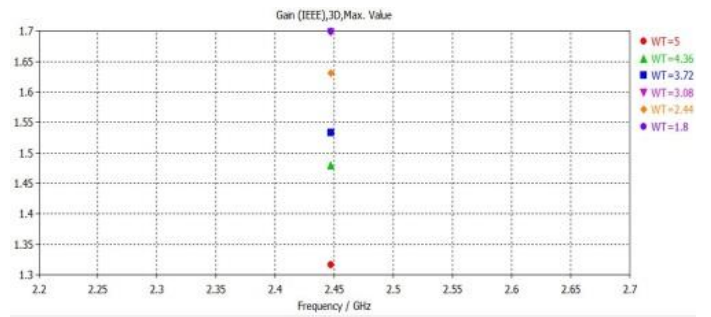

Gambar 23. Perubahan Dimensi WT Terhadap Gain

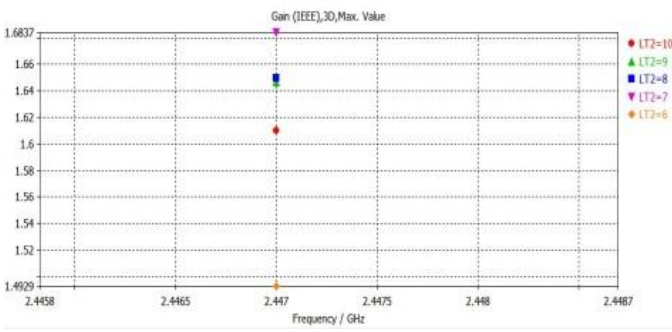

Gambar 24. Perubahan Dimensi LT2 Terhadap Gain

B. Hasil Optimasi Saluran Pencatu Simulasi Antena T-shaped slot pada CST dan ADS

Optimasi dilakukan dengan cara mengubah nilai dimensi panjang saluran pencatu dan menggeser posisi saluran pencatu microstrip line ke kiri maupun ke kanan. Pada Tabel 5 menunjukkan nilai dimensi panjang saluran pencatu dengan kondisi parameter yang baik yakni sebesar $24,56 \mathrm{~mm}$ dengan bandwidth sebesar $44 \mathrm{MHz}$.

Tabel 5. Hasil Optimasi Dimensi Panjang Strip Line

\begin{tabular}{ccccc}
\hline LST & rL (dB) & $\begin{array}{c}\text { Gain } \\
(\mathbf{d B})\end{array}$ & $\begin{array}{c}\text { BW } \\
(\mathbf{M H z})\end{array}$ & $\begin{array}{c}\text { Frek. } \\
\text { Center }\end{array}$ \\
\hline 33,56 & $-9,564$ & 1,5 & - & 2,502 \\
32,64 & $-9,482$ & 1,6 & - & 2,502 \\
30,72 & $-9,586$ & 1,68 & 15 & 2,499 \\
29,76 & $-9,631$ & 1,72 & 21 & 2,499 \\
28,8 & $-9,89$ & 1,7 & 41 & 2,498 \\
27,84 & $-9,949$ & 1,75 & 45 & 2,498 \\
24,56 & $-9,886$ & 2,21 & 44 & 2,494 \\
24 & $-9,963$ & 2,18 & 0 & 2,494 \\
\hline
\end{tabular}

Pada Tabel 6 dapat dilihat optimasi pergeseran saluran pencatu yang telah dilakukan. Bandwidth yang paling lebar yang dapat dihasilkan adalah sebesar $94 \mathrm{MHz}$ dengan frekuensi kerja yang dihasilkan adalah 2,357 GHz.

Tabel 6. Hasil Optimasi Pergeseran Posisi Mikrostrip Line

\begin{tabular}{ccccc}
\hline $\begin{array}{c}\text { Posisi } \\
\text { Saluran } \\
(\text { sumbu-x) }\end{array}$ & rL (dB) & $\begin{array}{c}\text { Gain } \\
(\mathbf{d B})\end{array}$ & $\begin{array}{c}\text { BW } \\
(\mathbf{M H z})\end{array}$ & $\begin{array}{c}\text { Frek. } \\
\text { Center } \\
(\mathbf{G H z})\end{array}$ \\
\hline-1 & $-39,109$ & 5,420 & 84 & 2,302 \\
$-1,2$ & $-17,15$ & 5,347 & 70 & 2,298 \\
$-0,8$ & $-21,268$ & 5,400 & 90 & 2,308
\end{tabular}




\begin{tabular}{ccccc}
\hline $\begin{array}{c}\text { Posisi } \\
\text { Saluran } \\
\text { (sumbu-x) }\end{array}$ & rL (dB) & $\begin{array}{c}\text { Gain } \\
(\mathbf{d B})\end{array}$ & $\begin{array}{c}\text { BW } \\
(\mathbf{M H z})\end{array}$ & $\begin{array}{c}\text { Frek. } \\
\text { Center } \\
(\mathbf{G H z})\end{array}$ \\
\hline$-0,7$ & $-18,374$ & 5,421 & 94 & 2,357 \\
$-0,5$ & $-12,45$ & 5,394 & 80 & 2,317 \\
$-0,2$ & $-10,514$ & 5,229 & 48 & 2,332 \\
1 & $-8,967$ & 5,042 & - & 2,408 \\
0,7 & $-8,717$ & 5,111 & - & 2,394 \\
\hline
\end{tabular}

Pada Tabel 7 dapat dilihat nilai hasil optimasi yang telah dilakukan dengan frekuensi kerja 2,447 $\mathrm{GHz}$ dan bandwidth yang lebar sebesar $102 \mathrm{MHz}$. Hal ini berarti dimensi panjang patch, dimensi saluran pencatu, dan posisi saluran pencatu sangat mempengaruhi bandwidth yang dihasilkan.

Tabel 7. Hasil Optimasi Pergeseran Frekuensi T-Shaped Slot

\begin{tabular}{ccccc}
\hline $\begin{array}{c}\text { PP(Panjang } \\
\text { Patch) }\end{array}$ & rL (dB) & $\begin{array}{c}\text { Gain } \\
(\mathbf{d B})\end{array}$ & $\begin{array}{c}\text { BW } \\
(\mathbf{M H z})\end{array}$ & $\begin{array}{c}\text { Frek. } \\
\text { Center } \\
(\mathbf{G H z})\end{array}$ \\
\hline 28,85 & $-18,374$ & 5,421 & 94 & 2,357 \\
27,78 & $-17,095$ & 5,339 & 99 & 2,394 \\
27,17 & $-16,195$ & 5,337 & 102 & 2,447 \\
\hline
\end{tabular}

a) Nilai Return Loss pada CST dan ADS

Grafik nilai return loss pada simulator CST dapat dilihat pada Gambar 25. Nilai minimum return loss yang dihasilkan berdasarkan simulasi adalah sebesar $-16,195 \mathrm{~dB}$ pada frekuensi kerja $2,447 \mathrm{GHz}$.

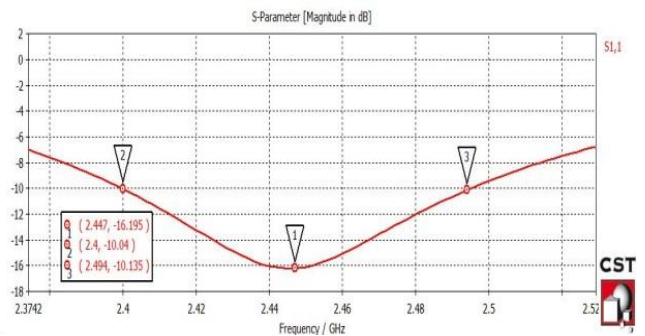

Gambar 25. Return Loss Hasil Optimasi Antena T-Shaped Slot CST

Dan pada Gambar 26 menunjukkan nilai return loss yang dihasilkan menggunakan simulator ADS. Pada frekuensi kerja 2,447 $\mathrm{GHz}$ nilai minimum return loss yang dihasilkan adalah sebesar 9,088 dB.

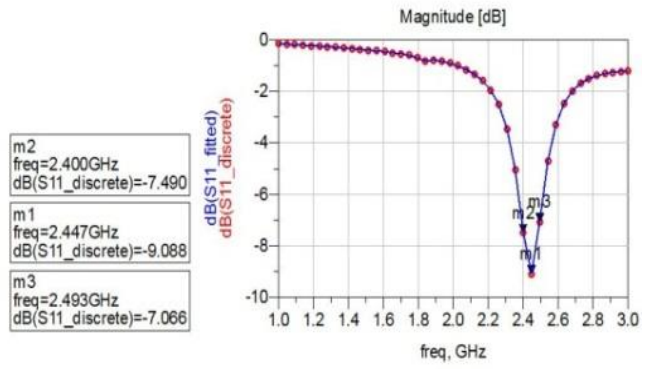

Gambar 26. Return Loss Hasil Optimasi Antena T-Shaped Slot ADS
Dari kedua grafik menunjukkan bahwa nilai return loss yang dihasilkan sudah memenuhi spesifikasi antena mikrostrip yakni $\leq-10 \mathrm{~dB}$.

b) Nilai VSWR pada CST dan ADS

Pada simulator CST nilai VSWR yang dihasilkan dapat dilihat berdasarkan Gambar 27, pada frekuensi kerja 2,447 $\mathrm{GHz}$ adalah sebesar 1,3668. Hal ini berarti, nilai VSWR yang didapat sudah memenuhi nilai spesifikasi vswr antena secara umum yakni $\leq 2$.

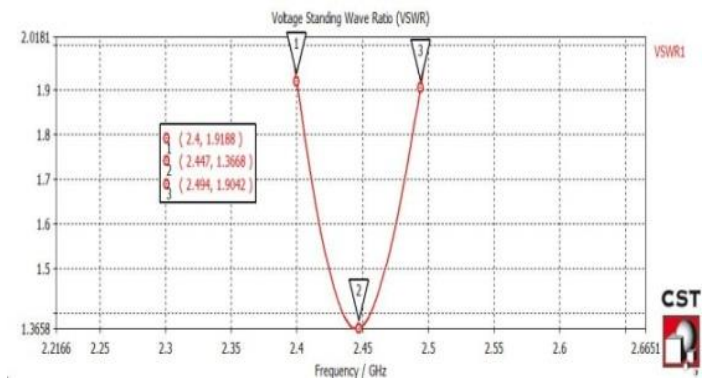

Gambar 27. VSWR Hasil Optimasi Antena T-Shaped Slot CST

Sementara itu, nilai VSWR yang dihasilkan menggunakan simulator ADS ditunjukkan pada Gambar 28. Pada frekuensi kerja 2,447 GHz menghasilkan VSWR sebesar 2,083.

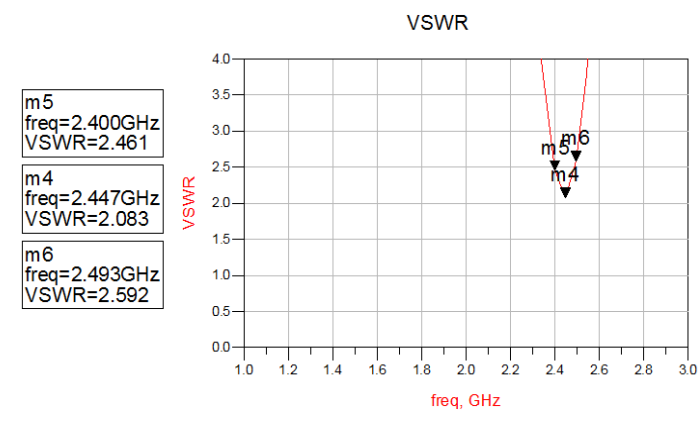

Gambar 28. VSWR Hasil Optimasi Antena T-Shaped Slot ADS

c) Nilai Gain pada CST dan ADS

Pada simulator CST gain yang dihasilkan ditunjukkan pada Gambar 29. Nilai gain yang didapat adalah sebesar 5,337 dB.

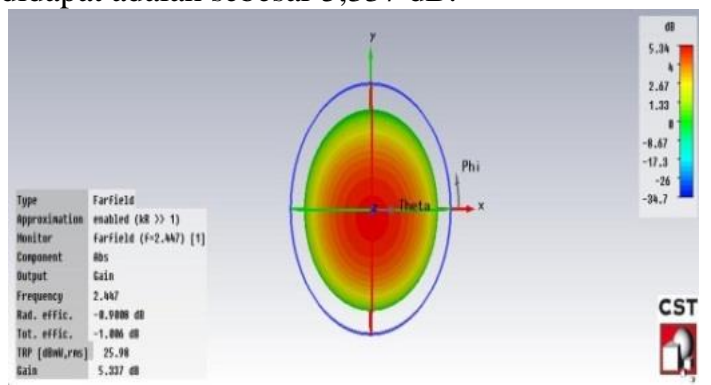

Gambar 29. Gain Hasil Optimasi Antena T-Shaped Slot Pada Simulator CST 


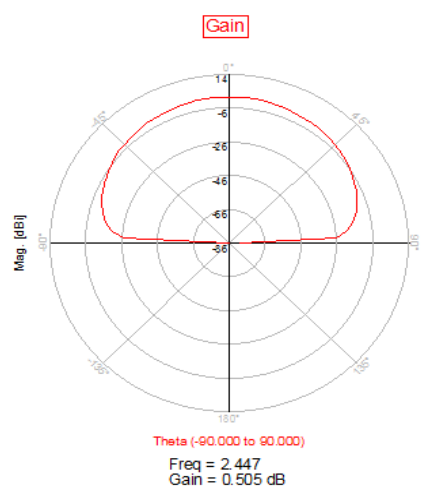

Gambar 30. Gain Hasil Optimasi Antena T-Shaped Slot ADS

Pada simulator ADS, nilai gain yang dihasilkan ditunjukkan pada Gambar 30. Hasil yang diperoleh untuk parameter gain adalah sebesar $0,505 \mathrm{~dB}$.

\section{d) Nilai Pola Radiasi pada CST dan ADS}

Pola radiasi yang dihasilkan diperlihatkan pada Gambar 31 dan Gambar 32. Berdasarkan gambar yang dihasilkan, pola radiasi yang dihasilkan berbentuk unidirectional.
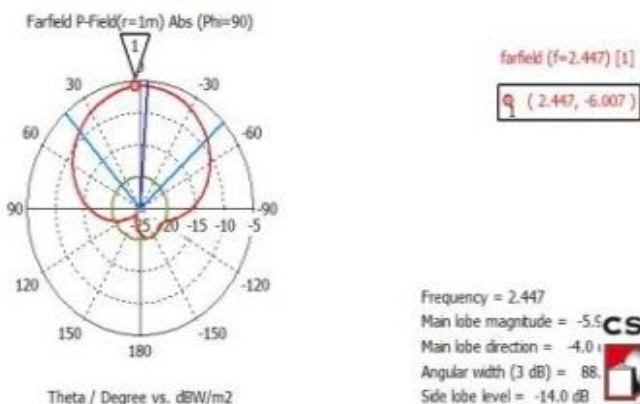

Theto / Degree vs. dow/m2

frequency $=24$

Man lobe magntude $=-5.5$ CST Main lobe drection $=-4.0$. Angular with $(3 \mathrm{~dB})=8 \mathrm{~B}$ Sde lobe level $=14.0$ at

Gambar 31. Pola Radiasi Hasil Optimasi Antena T-Shaped Slot Pada Simulator CST

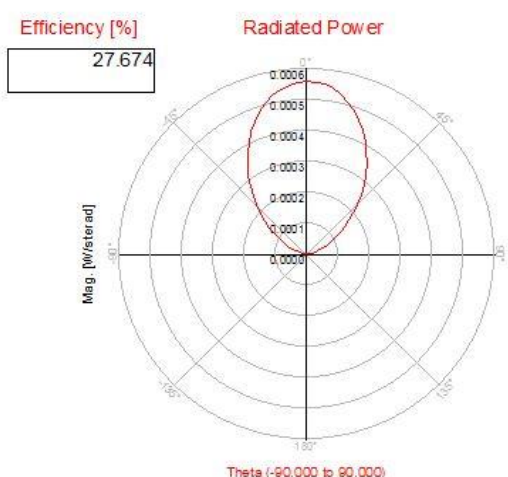

Gambar 32. Pola Radiasi Hasil Optimasi Antena T-Shaped Slot Pada Simulator ADS

e) Bandwidth Impedansi pada CST dan ADS

Pada Gambar 33, dapat dilihat bandwidth antena yang dihasilkan adalah sebesar $103 \mathrm{MHz}$. Persentase bandwidth antena dapat diperoleh sebesar $4,158 \%$.
Bandwidth antena yang dihasilkan lebih besar dibandingkan dengan bandwidth antena yang diinginkan sesuai dengan spesifikasi awal yakni sebesar $94 \mathrm{MHz}$ atau sekitar 3,84\%.

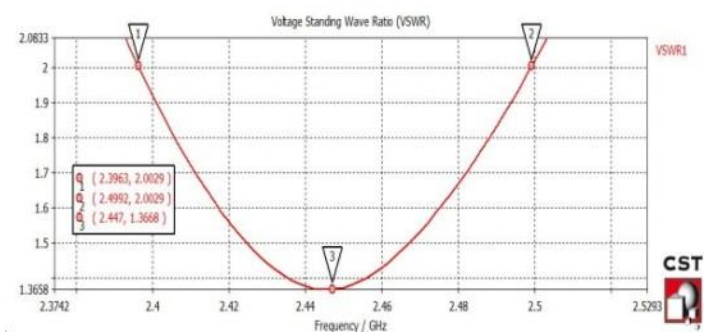

Gambar 33. Bandwidth Hasil Optimasi Antena T-Shaped Slot Pada Simulator CST

Pada Gambar 34, dapat dilihat bandwidth yang dihasilkan menggunakan simulator ADS tidak ada karena, VSWR tidak $\leq 2$.

VSWR

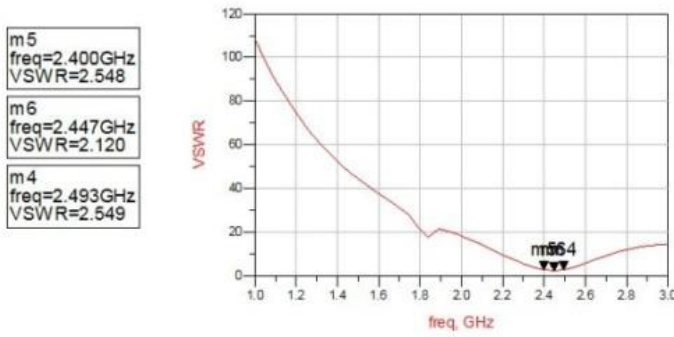

Gambar 34. Bandwidth Hasil Optimasi Antena T-Shaped Slot Pada Simulator ADS

f) Impedansi pada CST dan ADS

Impedansi yang diperoleh pada Gambar 35, menggunakan CST pada frekuensi 2,447 GHz adalah Zin $=45,175+\mathrm{j} 14,0935$.

Impedansi input pada frkuensi kerja 2,447 $\mathrm{GHz}$, dapat diperoleh dengan menggunakan persamaan sebagai berikut.

$$
\begin{aligned}
\operatorname{Zin} & =(\operatorname{Rin}+\mathrm{j} X \text { in }) \Omega \\
& =(45,1752+\mathrm{j} 14,093) \Omega \\
& =\sqrt{(45,1752)^{2}+(j 14,093)^{2}} \\
& =47,32 \Omega
\end{aligned}
$$

Berdasarkan kalkulasi yang telah dilakukan, nilai ini menunjukkan bahwa impedansi beban dengan impedansi saluran transmisi pada antena sudah dalam keadaan matching.

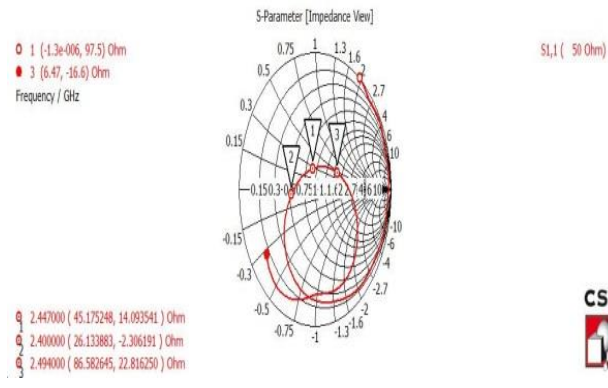

Gambar 35. Impedansi Hasil Optimasi Antena T-Shaped Slot Pada Simulator CST 
Impedansi yang dihasilkan ditunjukkan pada Gambar 36 menggunakan ADS, yakni pada frekuensi kerja 2,447 adalah sebesar 49,289+ j38, 192 .

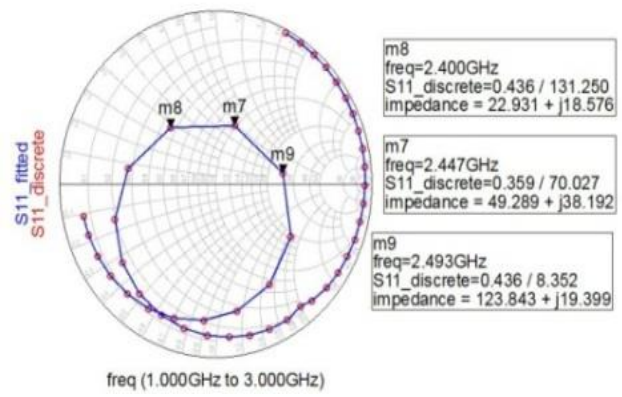

Gambar 36. Impedansi Hasil Optimasi Antena T-Shaped Slot Pada Simulator ADS

Impedansi input pada frekuensi kerja 2,447 $\mathrm{GHz}$, dapat diperoleh dengan menggunakan persamaan sebagai berikut.

$$
\begin{aligned}
\text { Zin } & =(\operatorname{Rin}+\mathrm{jXin}) \Omega \\
= & (49,289+\mathrm{j} 38,192) \Omega \\
= & \sqrt{(49,289)^{2}+(38,192)^{2}} \\
= & 62,354 \Omega
\end{aligned}
$$

Berdasarkan kalkulasi yang telah dilakukan, nilai impedansi masukan menunjukkan bahwa impedansi beban dengan impedansi saluran transmisi pada antena masih belum dalam keadaan matching.

\section{PENUTUP}

\section{A. Kesimpulan}

Perancangan antena T-shaped slot ini, dapat digunakan pada aplikasi Wi-Fi karena nilai VSWR dan return loss sudah memenuhi batas yang diijinkan pada frekuensi kerja $2,447 \mathrm{GHz}$ yakni $\mathrm{VSWR} \leq 2$. Metode komputansi Methode of Moment (MoM) pada simulator ADS tidak cukup mampu dan compatible dalam mensimulasikan rancangan antena mikrostrip T-shaped slot karena, metode ini tidak mendiskritasi seluruh volume dari rancangan. Sementara, pada simulator CST menggunakan metode komputansi Finite Integrate Technique (FIT) yang dapat mengamati seluruh volume dari model antena yang dirancang. Pada simulator CST return loss yang dihasilkan sebesar -16,195 dB, gain sebesar 5,337 dB, dan VSWR sebesar 1,367. Dan pada simulator ADS return loss yang dihasilkan sebesar $-9,088 \mathrm{~dB}$, gain sebesar 0,505 dB, dan VSWR sebesar 2,083. Perancangan antena mikrostrip T-shaped slot mampu menghasilkan bandwidth yang jauh lebih lebar untuk aplikasi Wi-Fi dibandingkan dengan antena mikrostrip rectangular. Dari hasil simulasi perancangan pada simulator CST, bandwidth yang dihasilkan antena mikrostrip T-shaped slot pada frekuensi kerja 2,447 GHz lebih dari $100 \%$ dari bandwidth yang dirancang yakni sebesar $103 \mathrm{MHz}$ dengan gain sebesar 5,337 dB dan return loss $-16,195$ $\mathrm{dB}$.

\section{DAFTAR PUSTAKA}

[1]. abd elrahman Younis Ali, Ruqaia. "The Advantages of Wi-Fi 802.11ac over 802.11n: A Comparative Study", International Journal of Engineering, Applied and Management Sciences Paradigms, Vol. 23, Issue 01.2015

[2]. James, J dan Hall PS. "Handbook of Microstrip Antennas". Peter Preregrinus Ltd, London. 1989.

[3]. Nugraha, Eka Setia. "Desain dan Realisasi Sistem Antena MIMO 2x2 Model PIFA Asymetric E-Shaped untuk modem berbasis WIMAX". Thesis, Universitas Telkom, Bandung, 2014.

[4]. Garg, R., Bhartia, P, Bahl, I., dan Ittipiboon, A. "Microstrip Antenna Design Handbook", Artech House Inc., Norwood, MA, 2001.

[5]. Balannis,Constantine. "Antenna Theory Analisys and Desain", Harper and Row, New York, 1982.

[6]. Dwi, Hantoro.G. "WiFi (Wireless LAN) Jaringan Komputer Tanpa Kabel", Informatika Bandung. 2009.

[7]. Boonachi Kaewchan, Watcharaphon Naktong, Amnoiry Ruengwaree. "T-shape slot in Rectangulr slot antenna to enlarge bandiwdth for broadband communication". University of Technology Thanyaburi, Thailand. 2010.

[8]. Rastantao Hadinegoro, Indra Surjati, and Yuli Kurnia ningsih. "Ultra Wideband Microstrip Antenna Using T-Shaped Stub Fed by Coplanar Waveguide". University of Industrial Technology Trisakti, Indonesia. 2013.

[9]. Kun Song, Ying-Zeng, Xiao-Bo Wu, and Li-Zhang. "Bandwidth Enhancement of Open Slot Antenna With A T-Shaped Stub". Xidian University, Republic of China. 2009.

[10]. M. Ravi Kishore, A. Janardhana, and B. Murali Krishna. "Design and Simulation of Dual Band TShaped Slot Microstrip Antenna for C-Band Applications". Int. Journal of Engineering Research and Technology, Vol. 4, Issue 09, September 2015.

[11]. D. M. Pozar. “Microwave Engineering”, 4th Ed. New york : John Wiley \& sons, Inc., 2012.

[12]. Budi,MP Imam. "Perancangan dan Analisis Antena Mikrostrip MIMO Circular Pada Frekuensi 2,35 Ghz Untuk Aplikasi LTE”, Jurnal Infotel Vol.9 No.1 Februari 2017.Indonesia. 2017

[13]. Yasin,A.Alaa. “ Dual-Band Microstrip Patch Antenna Design Using C-slot for Wifi and Wimax Applications", 5th International Conference on Computer \& Communication Engineering.2014 
ISSN : 2085-3688; e-ISSN : 2460-0997

Analisis Pengaruh T-Shaped Slot Terhadap Kualitas Parameter Antena Mikrostrip Menggunakan Computer Simulation Technology (CST) dan Advanced Design System (ADS) untuk Aplikasi Wi-Fi

[14]. Rutschlin,Mark." Phased Antenna Array Design with CST STUDIO SUITE", CST Computer Simulation Technology.2012

[15]. Prakash,A.Ram. "Design and Analysis of Circularly Polarized Slotted Microstrip Square Patch Antenna for Remote Vehicle Wireless Data Transfer", International Conference on Communication and Signal Processing. 2016. 